\title{
Needs of Comfort, Safety, Recognition of a Housing Design with a POE Approach, Case: Dliko Indah Housing Salatiga Indonesia
}

\author{
Djoko Indrosaptono*, Tri Susetyo Andadari, Alfanadi Agung Setiyawan \\ Department of Architectural Engineering, Diponegoro University, Semarang, Indonesia
}

Received February 27, 2021; Revised May 6, 2021; Accepted June 6, 2021

\section{Cite This Paper in the following Citation Styles}

(a): [1] Djoko Indrosaptono, Tri Susetyo Andadari, Alfanadi Agung Setiyawan, "Needs of Comfort, Safety, Recognition of a Housing Design with a POE Approach, Case: Dliko Indah Housing Salatiga Indonesia," Civil Engineering and Architecture, Vol. 9, No. 4, pp. 1097-1109, 2021. DOI: 10.13189/cea.2021.090412.

(b): Djoko Indrosaptono, Tri Susetyo Andadari, Alfanadi Agung Setiyawan (2021). Needs of Comfort, Safety, Recognition of a Housing Design with a POE Approach, Case: Dliko Indah Housing Salatiga Indonesia. Civil Engineering and Architecture, 9(4), 1097-1109. DOI: 10.13189/cea.2021.090412.

Copyright $\bigcirc 2021$ by authors, all rights reserved. Authors agree that this article remains permanently open access under the terms of the Creative Commons Attribution License 4.0 International License

\begin{abstract}
The number of housing needs for low-income people continues to increase every year, and the government and the private sector create affordable housing with decent housing according to Indonesian healthy housing standards. Dliko Indah Housing Salatiga is housing that was planned and designed in the form of housing units of various types that were built in the 1980s and still exist today. Dliko housing has been in existence for more than 30 years, and has undergone physical changes in various design elements. This condition is suspected of having several driving factors for residents to change it. Through the post occupancy evaluation (POE) method approach, it is hoped that the answers to the occupants' motivations can be obtained as to why they made these changes and at the same time obtain the driving factors. The aim of this research is that the results can be used as an evaluation in planning and designing similar housing developments in the future. The research method used is a qualitative rationalistic research approach, using stratified random sampling. Related theories and journals are used as a tool to analyze as well as direct research, and to obtain field data. The final result is a variation in the percentage of change rates for each of the elements that make up a simple home design such as: changes in KDB, building plans, functions, facades and changes in materials. These changes are the demands for Comfort, Security, and Recognition.
\end{abstract}

Keywords Comfort, Security, Recognition, Post Occupancy Evaluation, Dliko Indah Housing

\section{Introduction}

Salatiga City is divided into 4 districts, namely Argomulya District, Tingkir District, Sidomukti District and Sidorejo District. Based on data from the Central Statistics Agency for the city of Salatiga, until the end of 2016, Salatiga had a population of 186,420 . With an area of only $56,781 \mathrm{~km}^{2}$ Salatiga and a population density of around 9,800, the demand for housing of the people in Salatiga is quite high, especially for low-income people.

Anticipating this situation, the Regional Government of Salatiga City has collaborated with the private sector, in this case the developers to open housing and settlements with various types of houses, at affordable prices, especially for low-income groups (GMBR), in several locations in Salatiga City.

It is undeniable that the form of housing and settlement development carried out in the City of Salatiga currently places more emphasis on the supply approach, where housing and settlement development emphasizes efficiency, rationalization and standardization. As a result, the houses built are of a standard nature like those that are used universally throughout Indonesia. In fact, as we all 
know, not all of these standards match the wants and needs of residents who have different socio-cultural backgrounds and social status.

The form and system of housing which are standard in nature, encourage residents to make changes (transformation) to the dwellings they occupy, to match the wishes of the residents and the needs of the occupants. This transformation usually takes place with planning, both with careful planning, as well as planning as a quick solution to the problems of the inhabitants. In terms of funding, the transformation can be carried out with minimal funds, or for more capable residents, with funds that have been prepared in advance. Some residential owners change the form of dwelling, either moderately through modifications or extreme by building new dwellings, adjusting to the budget and image desired by the owner. This transformation based on the independence of the residents has made the face of housing become incompatible, even under certain conditions resulting in a pattern of unhealthy competition among residential residents.

The evaluation was carried out in three stages, indicative, investigative, and diagnostic [1].

The survey of modifications in the architectural design of the house reveals that there is a high level of dissatisfaction with the Typical Design provided by the Ministry. On the other hand, because Custom Design is closer to traditional houses from the point of view of the occupants' needs, the level of satisfaction is higher, although the beneficiaries indicated that traditional houses are more suitable for their lifestyle [2].

This approach allows us to separate claims originating from the design phase from those originating from the production phase. On the other hand, there are lessons for the enhanced project review in the licensing system, with the aim of increasing value in design, increasing supervision and site control. It also includes criticism of current standards and regulations, because in some cases they do not allow cities to meet value-in-design requirements [3].

Efforts to improve the safety aspects of low-cost housing construction are still being neglected and one of the reasons that can contribute to this factor is the low-price value. Therefore, Post Occupancy Evaluation (POE) was adopted to assess safety requirements. Besides that, the approach regarding hierarchical factors of safety elements and attributes as a design is the top priority needed [4].

The evaluation of housing performance is increasingly complex, as well as dynamics of occupant behavior, which adds to service complexity and expectations for all parties, resulting in a number of undesirable consequences and a higher risk of failure in performance [5].

The role of post-settlement evaluation plays a role in assessing the success or failure of low-income, independent housing settlements. The POE approach has great potential as well as the ability to determine whether the objectives of a project have been achieved. On the other hand, it can be used to formulate policy alternatives for future projects [6].

Participatory action research methodology through occupant-centered approaches is used to the design and construction of wall systems. Affordable local material is a major concern; in addition to that, direct involvement of local communities has been shown to have positive impacts and performance efficiency. POE has several stages, from simple to detail level, which are owner / occupant oriented, from academia to industry [7].

This POE study can provide insight into the interactions between buildings and their occupants, particularly in the context of modular construction, and further contribute to developing high-performance modular multi-residential buildings [8].

Research on occupancy that assesses quantitatively and compares long-term satisfaction to residents in relation to physical changes in housing, such as expansion, orientation and layout of space, number of rooms, lighting and ventilation are important factors. In this case, it requires attention, especially in the planning and design needed in the long term [9].

The POE approach can show the failure rate in the design and the successful performance of the facility, as well as describe the level of satisfaction for its occupants [10].

For this reason, there is a need for a post occupancy evaluation or post occupancy evaluation on housing, in this case housing managed by the private sector, to get a picture of the future, the form of housing that is appropriate and closer to the needs and desires (want) occupants.

The research was carried out at Dliko Indah Housing, which is an urban houses plan created by the private sector, which was previously intended for teachers and civil servants in Salatiga.

\section{Methodology}

The method used in this research is a qualitative rationalistic by looking at the transformation trend of the residential facade, changes in the basic building coefficient (KDB) of occupancy, changes in occupancy function, changes in residential plans, and changes in residential materials associated with the socio-economic conditions of the occupants. The sampling method used was the stratified random sampling technique, where from the type of house in Dliko Indah housing $10 \%$ of the houses were sampled to serve as a sample as a representative of the population. The size of the sample studied was 8 type 70 houses from a total of 80 units and 18 type 45 houses from a total of 180 units.

The qualitative rationalistic approach is very suitable when used for Post-Occupancy Evaluation in residential units that have taken place within a certain period of time. 
In terms of efforts to indicate the constraints and potentials of the built environment with the steps of the data collection method in the form of: document and archive evaluation, evaluation of questions, selected questionnaires and interviews.

\section{Theoretical Review}

\section{Post Occupancy Evaluation}

Post Occupancy Evaluation (POE) is an academic standard method used by scientists and consultants in the field of built areas and architecture to determine the extent to which architectural work and the built environment have an impact on its inhabitants. The impact referred to is the impact felt by residents of a built area, both tangible and intangible [11]. This method is used to determine the extent to which residents perceive the results of a built environment after more than 10 (ten) years of being inhabited.

The form of activity on a built environment, in the form of this evaluation, is carried out to determine the exact needs of residents, both implicitly and explicitly, where the final results of the evaluation can be used as input or feedback at the previous built environment design stage or as input for the design of a similar built environment in the future.

Preiser et al., [12] divides the level of evaluation effort into 3 categories, namely:

(a) Indicative Post-Occupancy Evaluation. It is an effort to indicate the constraints and potentials of the built environment by means of the data collection method in a row: evaluation of documents and files, evaluation of questions and selected interviews.

(b) Investigative Post-Occupancy Evaluation. It is a more complex post-occupation evaluation level, requires more time and requires more resources than the indicative level. It is generally carried out after an indicative level post-occupancy evaluation and has shown the results of any problems which can be further analyzed.

(c) Post-Occupancy Evaluation Diagnosis. It is an attempt of a deeper investigation. Evaluation at this level result in something aimed at improving certain facilities and the general condition of the type of built environment concerned.

\section{Urban Houses Plan}

Office of Public Works (DPU) [13] divides the definition of a house into 2 categories, namely:

(a) Simple house. It is a house building suitable for habitation, the part of which is directly above the ground, in the form of a single house, a duplex house and a row house. The price is affordable for low- and middle-income people. The building floor area is not more than $70 \mathrm{~m}^{2}$, which is built on land with a plot area of $54 \mathrm{~m}^{2}$ to $200 \mathrm{~m}^{2}$.

(b) Multi-story house. It is a house with two (2) or more floors, flats (flats) for both low-income groups (simple rental flats), middle-income groups (simple flats) and upper income groups (luxury flats apartments)

Meanwhile, according to Bell and Baron [14], the house is stated as follows, "In adapting to the home environment we develop more and more satisfactions with our ability to perform basic home making tasks in it, such as a child care and food preparation."

In other words, the function of the house cannot be separated from the function of a family [14], and the house is the facilitator for the running of a family's functions. In addition to the socialization function for residents, the house is also a place to build intimacy with surrounding neighbors.

As a result of a human built environment, the house conditions its residents to interact with fellow residents, who have a variety of behaviors. In the process of interaction, residents first interpret their environment, where this meaning is influenced by the frame of mind, norms and level of need.

The physical condition of the house and neighboring life influences the behavior of the residents of the housing. A discrepancy arises when there is dissatisfaction with one of the aspects mentioned above.

Morris \& Winter [15] divides aspects that are assessed by individuals or perceived by residents of housing into 5 things: space, ownership, type of house, quality of buildings and neighborhood life. These five aspects are influenced by several socio-demographic aspects, including income level, stages of family life development, education level, occupation, family structure and social status in society, as shown in Figure 1 diagram.

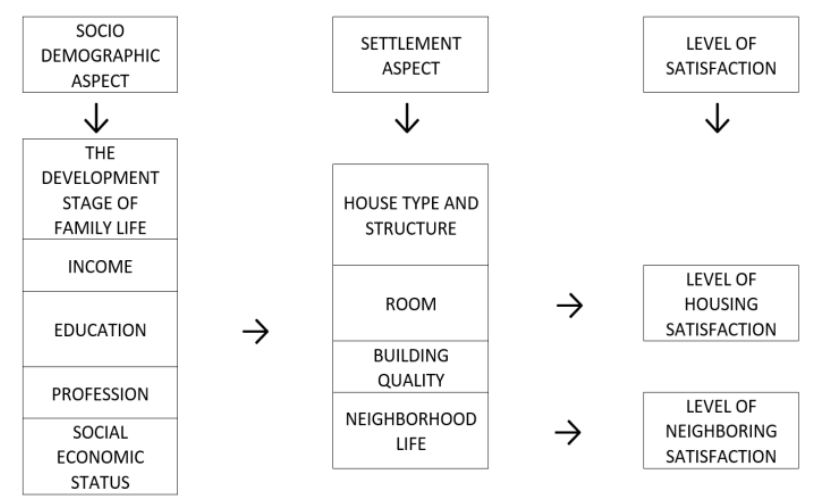

Source: compiled from Morris \& Winter [15]

Figure 1. Relationship's Chart between demographic and housing aspects

According to Morris \& Cook [16] there are several reactions made by residents of housing, if there is a discrepancy in one of the aspects above, namely: 
(a) Residential Mobility: Doing a move from a house that is currently occupied

(b) Residential alteration: Accepting and caring for a house that is inhabited as it is

(c) Residential Addition: improve and increase the space in a house that is occupied

Nutt et al., [17] revealed that occupant adjustment has 2 types, namely:

(a) Assimilation: It is an attempt to match a new experience to the knowledge and experiences a person has acquired at the previous time. The new experience is not only adjusted, but compared to the previous time.

(b) Accommodation: It shows the individual activity in modifying the scheme to suit new experiences.

Anderson and Carter [18] revealed that occupant adjustment has 2 types, namely:

(a) Assimilation. It is an attempt to match the new experience to the knowledge and experience a person has acquired at the previous time. The new experience is not only adjusted, but compared to the previous time.

(b) Accommodation. It shows the activity of individuals in modifying their schemes to suit new experiences.

In general, it can be concluded that the response of residents to conditions of dissatisfaction with the built environment is to avoid or make adjustments. The form of adjustment can be in the form of accepting the condition of the house as it is or making changes to the house to suit the needs of the occupants (adjustments).

Habraken [19] pointed out several factors that led to the tendency of residents to make changes to their houses, including:

(a) Identification: It is the need for self-introduction by considering the house as a means of identity

(b) Lifestyle: It is a life change that involves social and humanitarian aspects

(c) Technology: It is an invention in the field of technology that will affect the types and production systems

(d) Family Structure: It is a change that occurs in the family structure which results in changes in the level of needs and comfort in a place to live.

\section{Findings and Analysis}

\section{Dliko Indah Salatiga Housing}

Dliko Indah Housing, established around 1984, is developed by a private sector, namely PT Hasana Damai Putra. At the beginning of this housing development, the location of the housing estate was still outside the city limits of Salatiga, on the north side of the city of Salatiga. However, due to the expansion of the city of Salatiga, around the 1990s, Dliko Indah's housing estate became part of the city of Salatiga as shown in Figure 2.

The initial goal of the commencement of housing development in Dliko Indah was to provide housing needs for the people of Salatiga, with the main priority being for teachers and civil servants who at that time did not have houses which is deducted directly from the monthly salary of each prospective buyer.

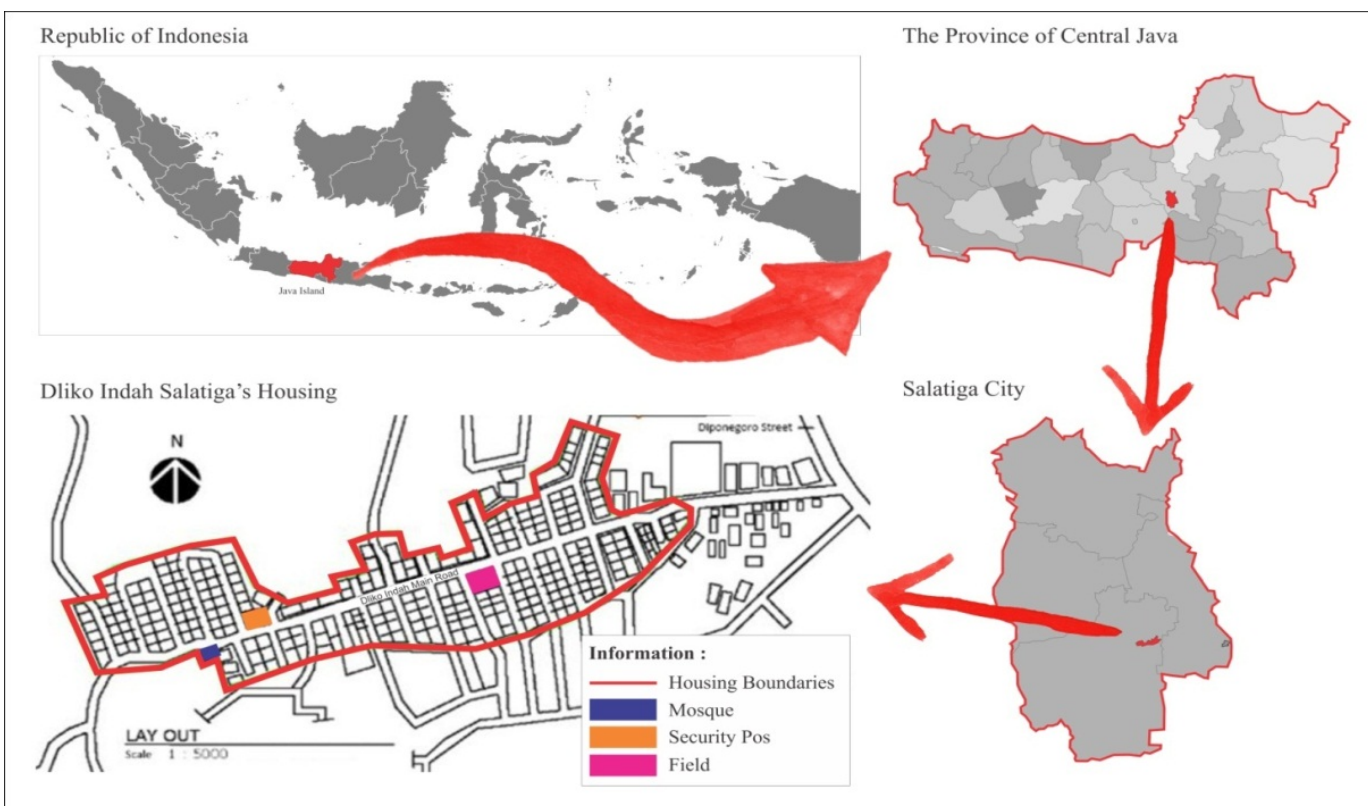

Source: Personal Analysis, 2018

Figure 2. Dliko Indah Salatiga's housing maps 
The initial objective of the commencement of the housing development in Dliko Indah was to provide housing for the people of Salatiga, with the main priority being teachers and civil servants who at that time did not have houses. Housing development is at the same time coordinating sustainable urban development [20]. The payment mechanism is the provision of a small down payment for prospective buyers and an installment payment that is deducted directly from the monthly salary of each prospective buyer.

The developer provides 2 types of houses in this housing, namely the type 45 house and the house type 70 . The type 45 house has a standard land area of approximately $100 \mathrm{~m}^{2}$ while the type 70 house has a standard land area of approximately $140 \mathrm{~m}^{2}$. The number of houses type 45 is provided with 180 units, while the house type 70 is only provided with 80 units of the total houses of 260 units.

In terms of funding, the developer works with the appointed bank, in this case Bank BTN, to become a third party that guarantees buyer funding.

The standard 45 type house has 2 bedrooms, 1 multipurpose room, 1 kitchen and 1 bathroom. The total area of standard land type 45 is $9.75 \mathrm{~m} \mathrm{x} 10.5 \mathrm{~m}$, if there is excess land, the buyer must pay the cost of excess land when the credit agreement is made with the guarantor bank.

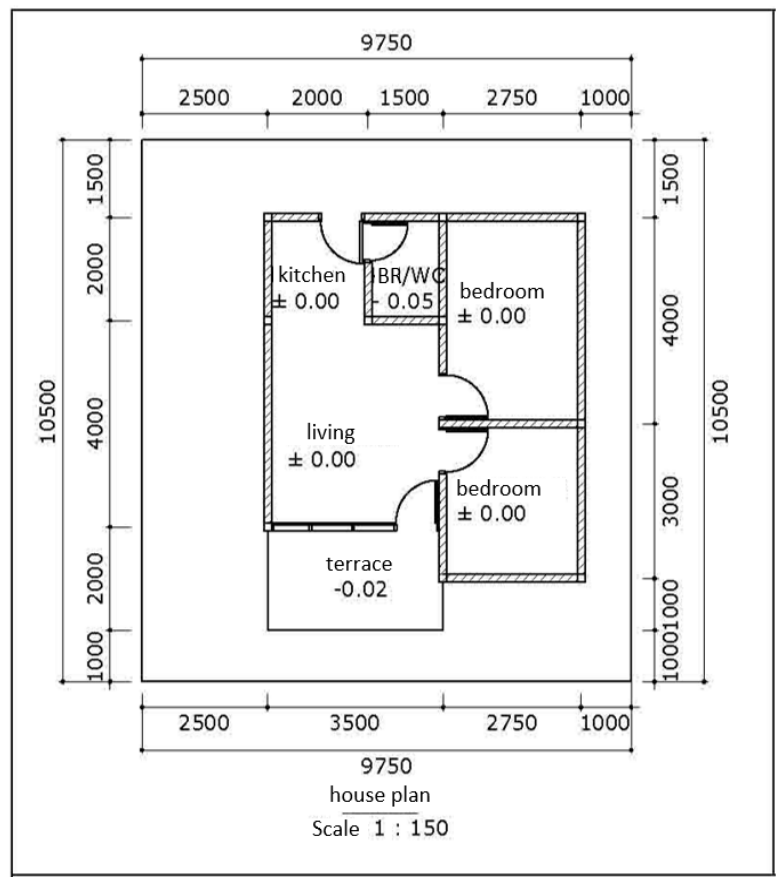

Source: personal analysis, 2018

Figure 3. Type 45 original house plan

Meanwhile, the type 70 house has 3 bedrooms, 1 multipurpose room, 1 kitchen and 1 bathroom. Figure 3 shows the original house plan type 45 and Figure 4 shows the original type 70 denal in Dliko Indah Salatiga housing.
The standard land area for type 70 is approximately 140 $\mathrm{m}^{2}$, with a length by a width of about $13.5 \mathrm{~m} \times 10.5 \mathrm{~m}$.

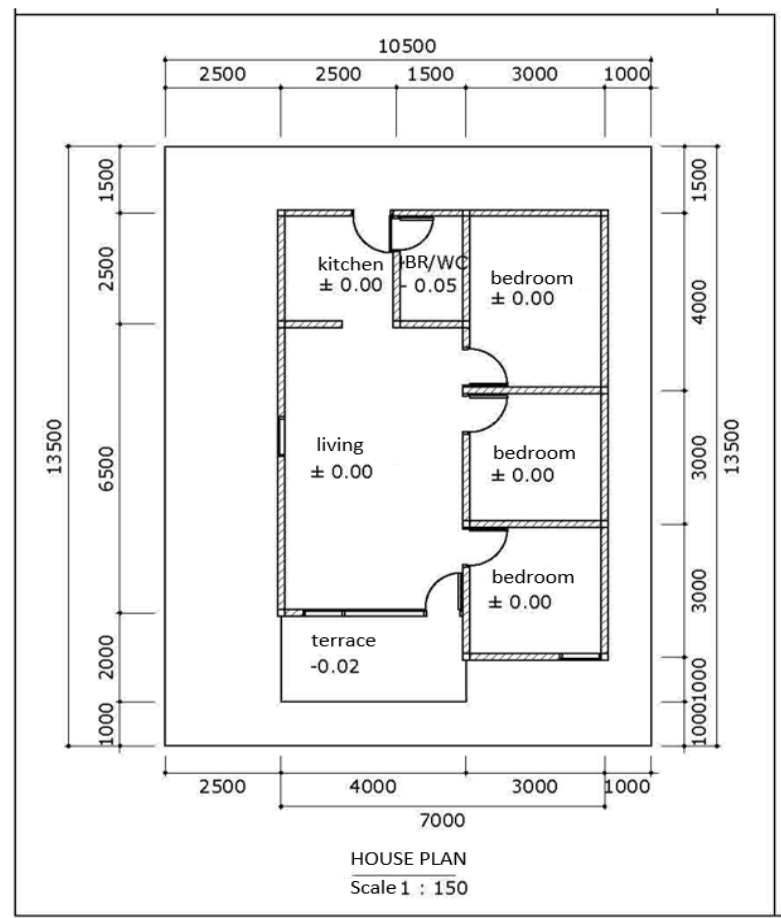

Source: personal analysis, 2018

Figure 4. Type 70 original house plan

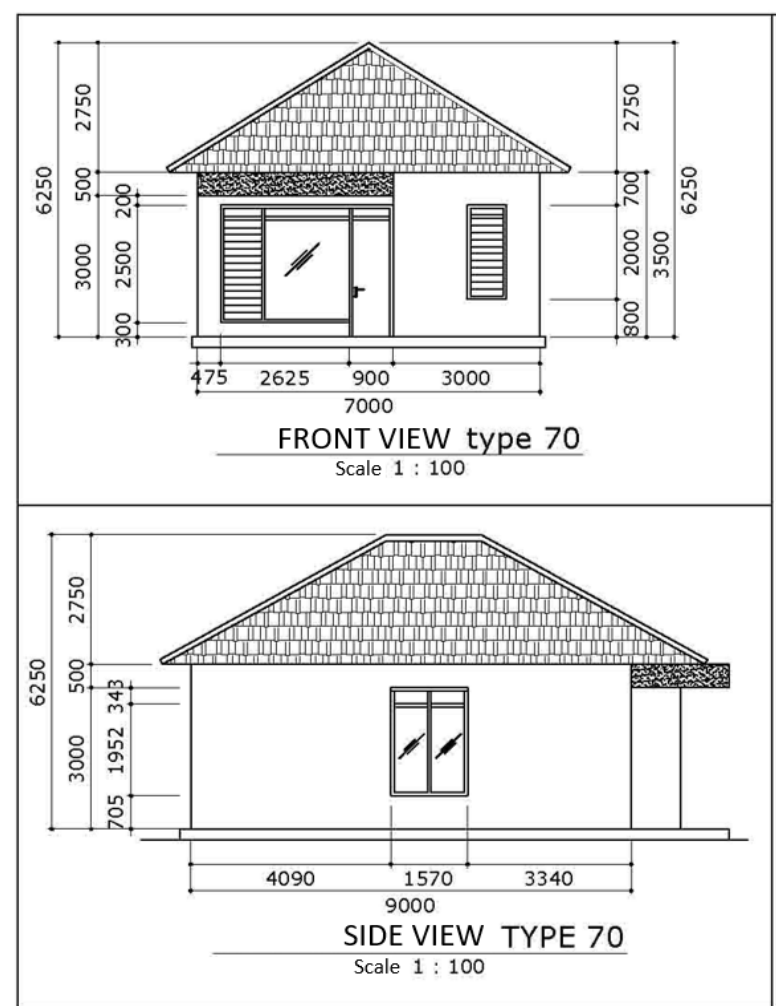

Source: personal analysis, 2018

Figure 5. Type 45 original house views

The form of the original building facade built by the developer is quite simple, with a pyramid-shaped roof, 
with non-concrete ornaments on the front side of the building to shade the terrace. The initial material was quite simple, only a masonry wall with plastered and plaster which was then finished with white wall paint the frame and window material are made of wood with a duco paint finish, and the middle is clear glass in the form of dead glass and nako. Tile using printed tile without finishing (Figure 5).

In addition to the fairly simple form of the building, the house in Dliko Indah housing is left to the owner in the form of a building without a fence around the house. The only land ownership limit provided by the developer is an iron stake planted at each end of the respective land boundary.

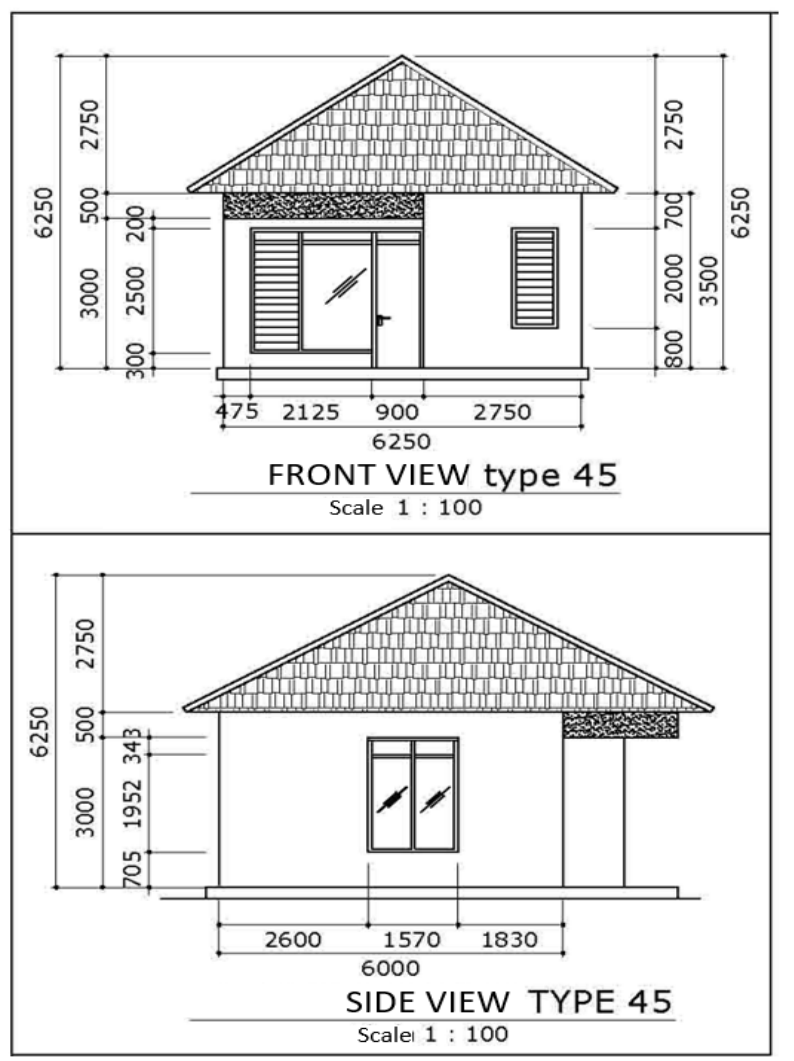

Source: personal analysis, 2018

Figure 6. Type 70 original house views

Without a fence, togetherness of the residents of the housing is created (Figure 6), because of frequent interactions with neighbors. From the developer side, not only preparing a house to be occupied by each buyer, but several public facilities have also been provided by the developer, such as a mosque, an open field for sports venues, a power grid system with the power entering each house $450 \mathrm{~W}$, clean water network system, dirty water network system, septic tank in each house, provision of environmental roads in the form of asphalt roads and housing gates as signage. Social facilities are an important part of the environment, because they can improve the quality of people's lives [21].

From the standard houses built by this developer, each occupant has undergone several transformations, according to the needs, desires and imaginations of each occupant [22].

Because the transformation of this residential form is carried out by individuals without involving the developer, it can be seen that the transformation is unplanned and in accordance with the financial conditions of each occupant [23]. The result is that the form of housing in general becomes irregular. There is an imbalance between those who are able to carry out a luxurious transformation or those who only make modest changes. There are differences in the number of residential floors. There are differences in the materials used and there are differences in the form of residential facades with various styles.

\section{1) Change in Basic Building Coefficient (KDB)}

This study used a stratified random sampling of $10 \%$ for each type of dwelling. The size of the sample studied was 8 type 70 houses from a total of 80 units and 18 type 45 houses from a total of 180 units.

According to the law in force in Indonesia, the basic building coefficient is around $60 \%$ of the land area. However, based on the results of field observations on samples at Dliko Indah Salatiga housing, it shows that there is an increase in building area or building coverage as shown in Table 1 below.

From the Table 1, it can be seen that there are efforts to increase the building area and ground floor area (Basic Building Coefficient and Building Coverage), both in the form of addition to 1 residential building with 1 floor, additional floors in 1 dwelling, or addition due to merging 2 residences into 1 large occupancy. For type 45, the initial building coverage provided by the developer is only $45 \%$, while for type 70 it is only $50 \%$.

The amount of increase in building coverage for type 45 housing was $84.84 \%$ or an increase of $39.84 \%$ while in type 70 the average was $77,78 \%$ or an increase of $27,78 \%$. 
Table 1. Changes in the Basic Building Coefficient (KDB) of Dliko Indah Salatiga Housing

\begin{tabular}{|c|c|c|c|c|c|}
\hline Sample & Land area $\left(\mathrm{M}^{2}\right)$ & Floor area 1 & Floor area 2 & Total Building Area & $\mathrm{BC}(\%)$ \\
\hline 1 & 162 & 120 & 0 & 120 & 74.07 \\
\hline 4 & 143 & 130 & 130 & 260 & 90.91 \\
\hline 11 & 220 & 115 & 0 & 115 & 52.27 \\
\hline 19 & 104 & 86 & 0 & 86 & 82.69 \\
\hline 26 & 140 & 116 & 0 & 116 & 82.86 \\
\hline $40 \mathrm{~A}-\mathrm{B}$ & 280 & 220 & 90 & 310 & 78.57 \\
\hline 60 & 100 & 84 & 36 & 120 & 84.00 \\
\hline 70 & 140 & 110 & 74 & 184 & 78.57 \\
\hline 75 & 100 & 90 & 68 & 158 & 90.00 \\
\hline 80 & 104 & 86 & 0 & 86 & 82.69 \\
\hline 92 & 100 & 84 & 0 & 84 & 84.00 \\
\hline 107 & 140 & 119 & 36 & 155 & 85.00 \\
\hline 110 & 122 & 68 & 0 & 68 & 55.74 \\
\hline 117 & 100 & 78 & 0 & 78 & 78.00 \\
\hline 127 & 100 & 88 & 64 & 152 & 88.00 \\
\hline 147A-B & 200 & 160 & 0 & 160 & 80.00 \\
\hline 158 & 100 & 86 & 86 & 172 & 86.00 \\
\hline 167 & 100 & 92 & 0 & 92 & 92.00 \\
\hline 175 & 100 & 88 & 52 & 140 & 88.00 \\
\hline 182 & 100 & 86 & 48 & 134 & 86.00 \\
\hline 187 & 100 & 92 & 0 & 92 & 92.00 \\
\hline 198 & 100 & 86 & 0 & 86 & 86.00 \\
\hline 208 & 100 & 88 & 36 & 124 & 88.00 \\
\hline 215 & 100 & 86 & 0 & 86 & 86.00 \\
\hline 223 & 100 & 86 & 0 & 86 & 86.00 \\
\hline 240 & 100 & 92 & 36 & 128 & 92.00 \\
\hline
\end{tabular}

Source: Personal Analysis, 2018

\section{2) House Plan Changes}

Broadly speaking, changes to residential plans, both in type 45 and type 70 , are divided into 3 categories, namely: changes to the floor plan only on the 1st floor, without any additional floors, changes to the plan due to an increase in the number of floors and the merger of 2 houses into 1 dwelling big.

Based on Table 1, it can be seen that the lowest percentage of Building Coverage in transformed dwellings is $52.27 \%$ (Figure 7) and the highest percentage of Building Coverage in transformed dwellings is $92 \%$ ((Figure 8).

Figure 7 and Figure 8 are examples of plans from field observations that have undergone a transformation in the Dliko Indah Salatiga housing estate, with the lowest and highest percentage of Building Coverage.

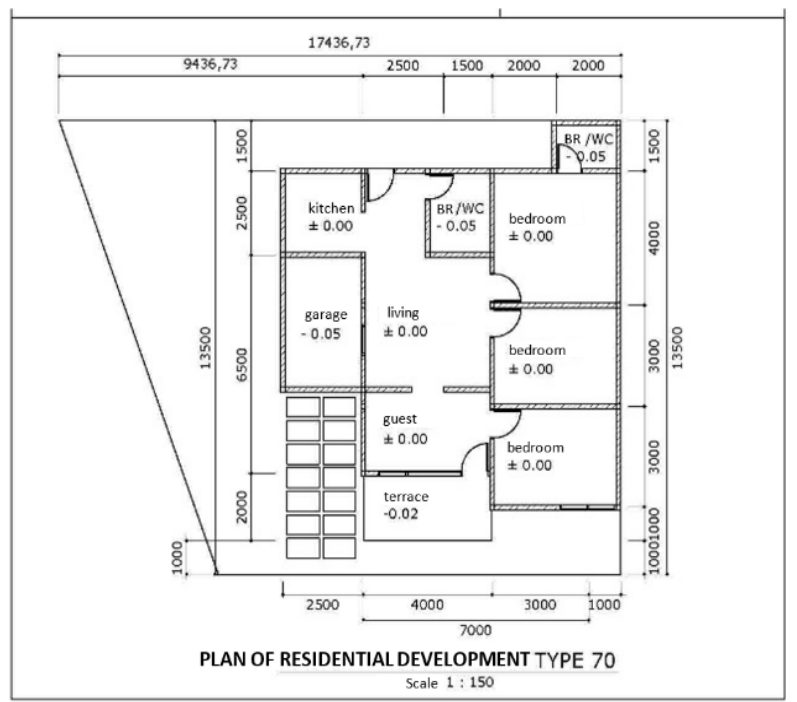

Source: personal analysis, 2018

Figure 7. Type 45 Residential Development Plan 


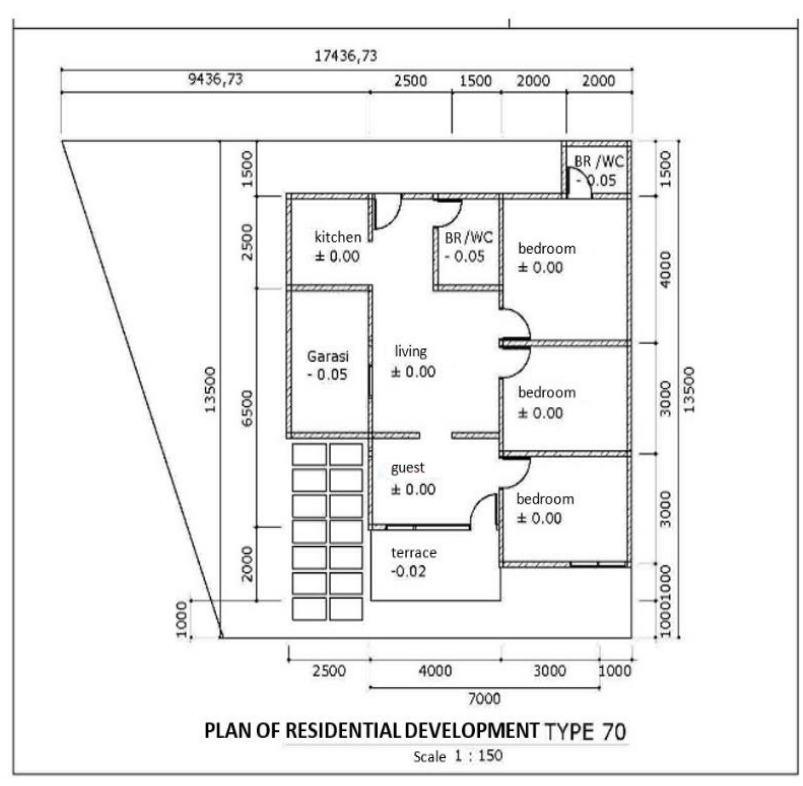

Source: personal analysis, 2018

Figure 8. Type 70 Residential Development Plan

\section{3) Changes in Home Functions}

The initial objective of the construction of the residential area in the Dliko Indah Salatiga housing complex was to meet the needs of the Salatiga community, especially teachers and civil servants, helping them have the opportunity to have decent housing with credit facilities. However, based on the results of observations in the field, it was found that there was a change in the function of the building from being purely a place to live, to being commercial, both purely commercial and semi-commercial and residential, on the grounds of increasing income or as an alternative source of income other than salary as a teacher or civil servant. The tabulation of changes in house function based on observations in the field at Dliko Indah Salatiga housing is shown in Table 2.

From Table 2, it can be seen that $4 \%$ of the buildings have undergone a total change into business premises, in this case offices. However, $31 \%$ experienced additional functions, not only as a building that functions as a residence, but also as a commercial building or business place, either in the form of shops, laundry, restaurants, catering, boarding houses or fashion.

Table 2. Table of Changes in the Function of the Dliko Indah Salatiga Residential Building

\begin{tabular}{|c|c|c|c|c|c|c|c|}
\hline \multirow[t]{2}{*}{ Sample } & \multicolumn{7}{|c|}{ Change in Building Function } \\
\hline & $\mathbf{A}$ & B & $\mathbf{C}$ & D & $\mathbf{E}$ & $\mathbf{F}$ & $\mathbf{G}$ \\
\hline 1 & $\mathrm{~V}$ & & & $\mathrm{~V}$ & & & \\
\hline 4 & $\mathrm{~V}$ & & & & & & \\
\hline 11 & $\mathrm{~V}$ & & & & & & \\
\hline 19 & $\mathrm{~V}$ & & $\mathrm{~V}$ & & & & \\
\hline 26 & $\mathrm{~V}$ & & & & & & \\
\hline $40 \mathrm{~A}-\mathrm{B}$ & $\mathrm{V}$ & & & & & & \\
\hline 60 & $\mathrm{~V}$ & & & & & & \\
\hline 70 & $\mathrm{~V}$ & & & & & & \\
\hline 75 & $\mathrm{~V}$ & & & & & & \\
\hline 80 & & & & & & $\mathrm{~V}$ & \\
\hline 92 & $\mathrm{~V}$ & & & & & & \\
\hline 107 & $\mathrm{~V}$ & $\mathrm{~V}$ & & & & & \\
\hline 110 & $\mathrm{~V}$ & $\mathrm{~V}$ & & & & & \\
\hline 117 & $\mathrm{~V}$ & & & & & & \\
\hline 127 & $\mathrm{~V}$ & $\mathrm{~V}$ & & & & & \\
\hline $147 \mathrm{~A}-\mathrm{B}$ & $\mathrm{V}$ & & & & & & \\
\hline 158 & $\mathrm{~V}$ & & & & & & \\
\hline 167 & $\mathrm{~V}$ & & & & & & \\
\hline 175 & $\mathrm{~V}$ & & & & $\mathrm{~V}$ & & \\
\hline 182 & $\mathrm{~V}$ & & & & & & \\
\hline 187 & $\mathrm{~V}$ & & & & & & \\
\hline 198 & $\mathrm{~V}$ & & & & & & \\
\hline 208 & $\mathrm{~V}$ & & & & & & \\
\hline 215 & $\mathrm{~V}$ & & & & & & $\mathrm{~V}$ \\
\hline 223 & $\mathrm{~V}$ & & & & & & \\
\hline 240 & $\mathrm{~V}$ & & & & & & \\
\hline 26 & 25 & 3 & 1 & 1 & 1 & 1 & 1 \\
\hline
\end{tabular}

$\mathrm{A}=$ Occupancy $\mathrm{B}=$ Shop $\mathrm{C}=$ Laundry $\mathrm{D}=$ Restaurant $\mathrm{E}=$ Catering $\mathrm{F}=$ Office $\mathrm{G}=$ Modiste

Source: Personal Analysis, 2018 
Table 3. Table of Spatial Changes in Dliko Indah Salatiga Housing

\begin{tabular}{|c|c|c|c|c|c|c|c|c|c|c|}
\hline \multirow[b]{2}{*}{ Sample } & \multicolumn{10}{|c|}{ Internal Spatial Changes } \\
\hline & $\begin{array}{c}\text { Living } \\
\text { room }\end{array}$ & Bedroom & $\begin{array}{c}\text { Family } \\
\text { room }\end{array}$ & Kitchen & Bathroom & $\begin{array}{c}\text { House } \\
\text { Shed }\end{array}$ & Garage & Carport & Terrace & Workspace \\
\hline 1 & 1 & 4 & 1 & 1 & 2 & 1 & 1 & 1 & 1 & 1 \\
\hline 4 & 1 & 4 & 1 & 1 & 3 & 0 & 1 & 1 & 1 & 0 \\
\hline 11 & 1 & 3 & 1 & 1 & 2 & 0 & 1 & 1 & 1 & 0 \\
\hline 19 & 1 & 4 & 1 & 1 & 2 & 1 & 1 & 1 & 1 & 1 \\
\hline 26 & 1 & 5 & 1 & 1 & 3 & 0 & 1 & 1 & 1 & 0 \\
\hline $40 \mathrm{~A}-\mathrm{B}$ & 1 & 6 & 1 & 1 & 3 & 0 & 1 & 1 & 1 & 0 \\
\hline 60 & 1 & 3 & 1 & 1 & 2 & 0 & 1 & 1 & 1 & 0 \\
\hline 70 & 1 & 3 & 1 & 1 & 2 & 0 & 1 & 1 & 1 & 0 \\
\hline 75 & 1 & 4 & 1 & 1 & 2 & 0 & 1 & 1 & 1 & 0 \\
\hline 80 & 1 & 1 & 1 & 1 & 1 & 1 & 1 & 1 & 1 & 2 \\
\hline 92 & 1 & 4 & 1 & 1 & 1 & 0 & 1 & 1 & 1 & 0 \\
\hline 107 & 1 & 3 & 1 & 1 & 2 & 1 & 1 & 1 & 1 & 1 \\
\hline 110 & 1 & 3 & 1 & 1 & 1 & 0 & 1 & 1 & 1 & 1 \\
\hline 117 & 1 & 3 & 1 & 1 & 2 & 0 & 1 & 1 & 1 & 0 \\
\hline 127 & 1 & 3 & 1 & 1 & 2 & 0 & 1 & 1 & 1 & 1 \\
\hline $147 \mathrm{~A}-\mathrm{B}$ & 1 & 5 & 1 & 1 & 1 & 0 & 1 & 1 & 1 & 0 \\
\hline 158 & 1 & 4 & 1 & 1 & 2 & 0 & 1 & 1 & 1 & 0 \\
\hline 167 & 1 & 4 & 1 & 1 & 2 & 0 & 1 & 1 & 1 & 0 \\
\hline 175 & 1 & 2 & 1 & 1 & 1 & 1 & 1 & 1 & 1 & 1 \\
\hline 182 & 1 & 3 & 1 & 1 & 1 & 0 & 1 & 1 & 1 & 0 \\
\hline 187 & 1 & 3 & 1 & 1 & 1 & 0 & 1 & 1 & 1 & 0 \\
\hline 198 & 1 & 3 & 1 & 1 & 2 & 0 & 1 & 1 & 1 & 0 \\
\hline 208 & 1 & 4 & 1 & 1 & 2 & 0 & 1 & 1 & 1 & 0 \\
\hline 215 & 1 & 4 & 1 & 1 & 2 & 0 & 1 & 1 & 1 & 1 \\
\hline 223 & 1 & 3 & 1 & 1 & 1 & 0 & 1 & 1 & 1 & 0 \\
\hline 240 & 1 & 3 & 1 & 1 & 1 & 0 & 1 & 1 & 1 & 0 \\
\hline
\end{tabular}

Source: Personal Analysis, 2018

\section{4) Changes in Inner Spatial}

The initial standard of interior layout provided by the developer at Dliko Indah Salatiga housing for type 45 consists of 2 bedrooms, 1 multipurpose room, 1 kitchen and 1 bathroom, while for house type 70, it consists of 3 bedrooms, 1 multipurpose room, 1 kitchen and 1 bathroom.

Field observations show that the Dliko Indah Salatiga housing estate has experienced additional space as shown in the Table 3.

From the results of the above observations, it can be seen that all dwellings, both type 45 and type 70 , have undergone changes and additions to the function of space. The addition and change of space depend on many factors, including an increase in the number of residents, increasing age of occupants, changes in occupancy function, increasing income levels of residents, the desire of residents to show their existence in the environment and so on.

As many as $73 \%$ of the respondents added space functions horizontally and $23 \%$ of the respondents added space functions both horizontally and vertically, the addition of space functions found in all dwellings, namely: living room, bedroom, family room, kitchen, bathroom, garage, carport and terrace, while warehouse and workspace were only added by a few respondents.

\section{5) Facade Changes}

Changes in building facades to self-identity and reflect the identity of the owner of the residence. With different educational backgrounds, income, preference levels and living needs, the building façade of Dliko Indah housing has also changed to be more varied with various architectural styles, such as minimalism, modern, futuristic, traditional or folk architecture. 
In the past, the standard building facade for both type 45 and type 70 houses was quite simple. The exterior walls are only finished with white mono color wall paint. Frames, dead windows, live windows and doors, only use wood with brown duco paint. The roof uses printed tiles without finishing. The floor uses only $20 \times 20 \mathrm{~mm}$ gray tiles. There is no land guardrail, there is also no fence on the front side of the dwelling and there is no minimum 1 tree provided as required by the government for occupancy with a minimum area of $80 \mathrm{~m}^{2}$

Table 4 below is a tabulation of the facade changes made by each occupant of the Dliko Indah Salatiga housing complex.

From Table 4, it can be seen that, to reinforce and clarify the boundaries of residential land, $100 \%$ of the residents fenced the brick masonry on the back, right and left sides of each dwelling with a minimum height of $3 \mathrm{~m}$. Apart from being the occupant's territory boundary, the installation of this earth fence aims to provide a sense of security for the residents in it. On the front side, $4 \%$ of residents do not fence it and leave it open, but the remaining $96 \%$ fence the front of the house with a height of about $1.5 \mathrm{~m}$ with an average of 2 door accesses, namely 1 door for pedestrian access and 1 door great for car access.

$100 \%$ of the residents take advantage of building boundaries that should be free from environmental roads, with various new functions, such as adding a terrace, adding bedrooms, changing functions for business premises, adding a garage and adding a pool and home garden.

Table 4. Table of Changes in the Facade of Dliko Indah Salatiga Residential Building

\begin{tabular}{|c|c|c|c|c|c|}
\hline House Number & Earth Fence & Front Fence & Utilization of Gsb & Imb Renewal & Tree \\
\hline 1 & $\mathrm{~V}$ & $\mathrm{~V}$ & $\mathrm{~V}$ & $\mathrm{X}$ & $\mathrm{X}$ \\
\hline 4 & $\mathrm{~V}$ & $\mathrm{X}$ & $\mathrm{V}$ & $\mathrm{X}$ & $\mathrm{X}$ \\
\hline 11 & $\mathrm{~V}$ & $\mathrm{~V}$ & $\mathrm{~V}$ & $\mathrm{X}$ & $\mathrm{X}$ \\
\hline 19 & $\mathrm{~V}$ & $\mathrm{~V}$ & $\mathrm{~V}$ & $\mathrm{X}$ & $\mathrm{X}$ \\
\hline 26 & $\mathrm{~V}$ & $\mathrm{~V}$ & $\mathrm{~V}$ & $\mathrm{X}$ & $\mathrm{X}$ \\
\hline $40 \mathrm{~A}-40 \mathrm{~B}$ & $\mathrm{~V}$ & $\mathrm{~V}$ & $\mathrm{~V}$ & $\mathrm{X}$ & $\mathrm{V}$ \\
\hline 60 & $\mathrm{~V}$ & $\mathrm{~V}$ & $\mathrm{~V}$ & $\mathrm{X}$ & $\mathrm{X}$ \\
\hline 70 & $\mathrm{~V}$ & $\mathrm{~V}$ & $\mathrm{~V}$ & $\mathrm{X}$ & $\mathrm{X}$ \\
\hline 75 & $\mathrm{~V}$ & $\mathrm{~V}$ & $\mathrm{~V}$ & $\mathrm{X}$ & $\mathrm{X}$ \\
\hline 80 & $\mathrm{~V}$ & $\mathrm{~V}$ & $\mathrm{~V}$ & $\mathrm{X}$ & $\mathrm{X}$ \\
\hline 92 & $\mathrm{~V}$ & $\mathrm{~V}$ & $\mathrm{~V}$ & $\mathrm{X}$ & $\mathrm{X}$ \\
\hline 107 & $\mathrm{~V}$ & $\mathrm{~V}$ & $\mathrm{~V}$ & $\mathrm{X}$ & $\mathrm{V}$ \\
\hline 110 & $\mathrm{~V}$ & $\mathrm{~V}$ & $\mathrm{~V}$ & $\mathrm{X}$ & $\mathrm{V}$ \\
\hline 117 & $\mathrm{~V}$ & $\mathrm{~V}$ & $\mathrm{~V}$ & $\mathrm{X}$ & $\mathrm{X}$ \\
\hline 127 & $\mathrm{~V}$ & $\mathrm{~V}$ & $\mathrm{~V}$ & $\mathrm{X}$ & $\mathrm{X}$ \\
\hline $147 \mathrm{~A}-147 \mathrm{~B}$ & $\mathrm{~V}$ & $\mathrm{~V}$ & $\mathrm{~V}$ & $\mathrm{X}$ & $\mathrm{V}$ \\
\hline 158 & $\mathrm{~V}$ & $\mathrm{~V}$ & $\mathrm{~V}$ & $\mathrm{X}$ & $\mathrm{V}$ \\
\hline 167 & $\mathrm{~V}$ & $\mathrm{~V}$ & $\mathrm{~V}$ & $\mathrm{X}$ & $\mathrm{X}$ \\
\hline 175 & $\mathrm{~V}$ & $\mathrm{~V}$ & $\mathrm{~V}$ & $\mathrm{X}$ & $\mathrm{X}$ \\
\hline 182 & $\mathrm{~V}$ & $\mathrm{~V}$ & $\mathrm{~V}$ & $X$ & $\mathrm{~V}$ \\
\hline 187 & $\mathrm{~V}$ & $\mathrm{~V}$ & $\mathrm{~V}$ & $X$ & $\mathrm{~V}$ \\
\hline 198 & $\mathrm{~V}$ & $\mathrm{~V}$ & $\mathrm{~V}$ & $X$ & $X$ \\
\hline 208 & $\mathrm{~V}$ & $\mathrm{~V}$ & $\mathrm{~V}$ & $X$ & $X$ \\
\hline 215 & $\mathrm{~V}$ & $\mathrm{~V}$ & $\mathrm{~V}$ & $X$ & $\mathrm{~V}$ \\
\hline 223 & $\mathrm{~V}$ & $\mathrm{~V}$ & $\mathrm{~V}$ & $X$ & $\mathrm{~V}$ \\
\hline 240 & $\mathrm{~V}$ & $\mathrm{~V}$ & $\mathrm{~V}$ & $X$ & $\mathrm{X}$ \\
\hline
\end{tabular}

Source: Personal Analysis, 2018 
At the beginning of residential development, the developer has arranged a Building Construction Permit as one of the conditions for a credit agreement in accordance with applicable laws and regulations with the area of land built according to each type, namely type 45 and type 70 . The function of this space does not necessarily encourage residents to renew the IMB, as seen in the table above, that $100 \%$ of the respondents when interviewed did not renew the IMB. Planting at least 1 tree according to government regulations, only $35 \%$ of the respondents did. The remaining $65 \%$ did not plant at least 1 tree in a residential area.

Below are some examples of photos of facade changes made by each occupant of the Dliko Indah Salatiga housing estate, according to the economic capacity of each and the tastes of each occupant.
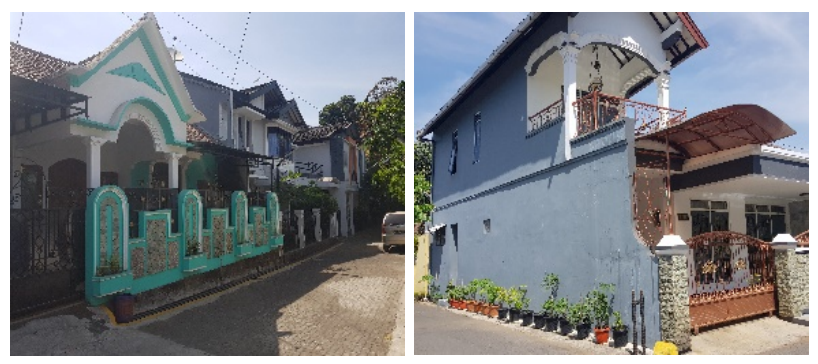
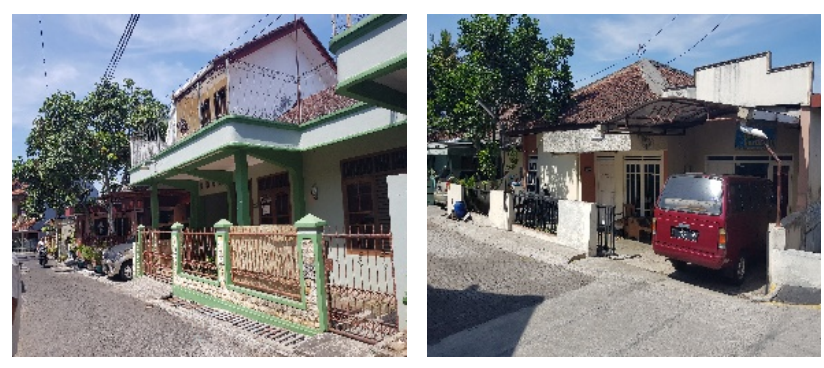

Source: Personal Analysis, 2018

Figure 9. Examples of some Residential Facade Changes

\section{6) Changes in building materials}

The specifications of the materials used at the start of the construction of the Dliko Indah Salatiga housing complex are quite simple according to Indonesian healthy home standards. The main structure is reinforced concrete. The foundation uses stone masonry. The walls use a pair of bricks in plaster and neatly finished with white wall paint. Frames, windows and doors use bengkirai wood with a duco finish, the roof uses printed bricks without finishing, and the floor uses $20 \times 20 \mathrm{~mm}$ gray tiles and the ceiling uses $1 \times 1 \mathrm{~m}$ plasterboard material.

Based on the results of field observations, there were several changes in the use of materials in the housing in Dliko Indah Salatiga Housing, as shown in the Table 5.

Table 5. Table of Changes in Housing Material for Dliko Indah Salatiga Housing

\begin{tabular}{|c|c|c|c|c|c|c|c|}
\hline \multirow[b]{2}{*}{ Sample } & \multicolumn{7}{|c|}{ Residential Material Change } \\
\hline & Floor & $\begin{array}{l}\text { Front } \\
\text { Fence }\end{array}$ & $\begin{array}{c}\text { Frames, Doors, } \\
\text { Windows }\end{array}$ & Ceiling & Paint & Roof & Carport \\
\hline 1 & ceramics & Iron & wood & gypsum & Wall & Glasur & concrete rebates \\
\hline 4 & ceramics & Iron & aluminum & gypsum & white & Glasur & concrete rebates \\
\hline 11 & ceramics & stainless & wood & gypsum & colored & Glasur & grass block \\
\hline 19 & ceramics & concrete & wood & gypsum & colored & Original with Addition & concrete rebates \\
\hline 26 & ceramics & Iron & wood & gypsum & colored & Original with Addition & paving block \\
\hline 40A-B & ceramics & Iron & wood & gypsum & colored & Glasur & concrete rebates \\
\hline 60 & ceramics & stainless & wood & gypsum & colored & press & concrete rebates \\
\hline 70 & ceramics & Iron & aluminum & plasterboard & colored & Original with Addition & concrete rebates \\
\hline 75 & ceramics & Iron & aluminum & gypsum & colored & Original with Addition & concrete rebates \\
\hline 80 & ceramics & stainless & wood & gypsum & colored & Original with Addition & grass block \\
\hline 92 & ceramics & Iron & wood & gypsum & white & Original with Addition & concrete rebates \\
\hline 107 & ceramics & $\mathrm{Brc}$ & wood & plasterboard & colored & Original with Addition & ceramics \\
\hline 110 & ceramics & Iron & wood & plasterboard & white & Original with Addition & concrete rebates \\
\hline 117 & ceramics & stainless & aluminum & gypsum & colored & Original with Addition & concrete rebates \\
\hline 127 & ceramics & stainless & wood & gypsum & colored & Original with Addition & concrete rebates \\
\hline 147A-B & ceramics & Iron & wood & gypsum & colored & Glasur & concrete rebates \\
\hline 158 & ceramics & Iron & aluminum & gypsum & colored & Ori & paving block \\
\hline 167 & ceramics & $\mathrm{Brc}$ & aluminum & gypsum & white & Original with Addition & paving block \\
\hline 175 & ceramics & Iron & wood & plasterboard & colored & Original with Addition & concrete rebates \\
\hline 182 & ceramics & Iron & wood & plasterboard & colored & Original with Addition & concrete rebates \\
\hline 187 & ceramics & $\mathrm{Brc}$ & wood & plasterboard & colored & Original with Addition & concrete rebates \\
\hline 198 & ceramics & Iron & wood & plasterboard & colored & Original with Addition & concrete rebates \\
\hline 208 & ceramics & Iron & wood & plasterboard & colored & Glasur & concrete rebates \\
\hline 215 & ceramics & Iron & wood & gypsum & colored & Original with Addition & concrete rebates \\
\hline 223 & ceramics & $\mathrm{Brc}$ & wood & plasterboard & colored & Original with Addition & concrete rebates \\
\hline 240 & ceramics & stainless & wood & plasterboard & colored & Original with Addition & concrete rebates \\
\hline
\end{tabular}


From Table 5, it can be seen that all residential samples have undergone a change in the type of material used on the floor, from the floor with $20 \times 20 \mathrm{~cm}$ gray tiles to ceramic floors of various sizes, colors, textures and motifs.

The addition of fences and carports occurred in all samples studied. The use of material for fences varies with the highest material being iron, which is $58 \%$, and then the second place is the use of stainless by $23 \%$, then BRC by $15 \%$ and concrete by $4 \%$. For carport material, $80 \%$ of the samples used concrete rebates, $12 \%$ used paving blocks, $8 \%$ used grass blocks and $4 \%$ used ceramics.

Some of the samples still used the same frame, window and door material as the original developer material, which was $76 \%$. It is just that the type of wood, type of finish and shape are not what they were originally.

$40 \%$ of the samples still use plasterboard as a ceiling covering material, while the remaining $60 \%$ have changed the ceiling from plasterboard to gypsum material with various profiling ornaments on the cornices and drop ceiling.

All samples were repainted on the walls of the building, either because the shape of the walls had changed; the old paint was fading and starting to dull or because of the addition of new walls to the dwelling. Only $16 \%$ of the sample retains the white color of the transformed shelters, while the rest choose to use other colors.

The use of roofs is still the same both in the initial building and in transformed dwellings, namely using a press roof. $20 \%$ of the samples used a tile press with a glaze finish, while the remaining $80 \%$ used a tile press as at the beginning of residential construction but experienced the addition of various roofing materials in the form of asbestos, zincallum, etc. in the additional buildings.

In general, the socio-demographic aspect is very influential in the occurrence of changes in the basic building coefficient (KDB), changes in occupancy plans, changes in residential functions, and changes in spatial planning in dwellings, changes in residential facades and changes in residential materials, where the pattern of the relationship can be seen in the Table 6 .

The opinions of residents are also very influential in changes in the basic coefficient of buildings (KDB), changes in residential plans, changes in residential functions, changes in residential spatial planning, changes in residential facades and changes in residential materials. In this case the relationship pattern can be seen in the table 7.

Table 6. Table of Relationship of Socio-Demographic Aspects to the Formation of Changes in Dliko Indah Salatiga Housing

\begin{tabular}{|c|c|c|c|c|c|}
\hline \multirow{2}{*}{ Socio Demographic Factors } & \multicolumn{5}{|c|}{ Post-Occupancy Change } \\
\cline { 2 - 6 } & KDB & House Plan & Home Functions & Façade Form & Material \\
\hline The stages of development in family life & SA & SA & SA & A & A \\
\hline Income & SA & SA & SA & A & A \\
\hline Education & A & A & SA & A & A \\
\hline Profession & A & A & SA & SA & SA \\
\hline Socioeconomic status & A & SA & SA & SA & SA \\
\hline
\end{tabular}

$\mathrm{SA}=$ Strongly Affects, $\mathrm{A}=$ Affects

Source: Personal Analysis, 2018

Table 7. List of Relationships from Respective Aspects about the Form of Change in Dliko Indah Housing Salatiga

\begin{tabular}{|c|c|c|c|c|c|}
\hline \multirow{2}{*}{ Residence Opinions } & \multicolumn{5}{|c|}{ Post - Occupancy Change } \\
\cline { 2 - 7 } & $\begin{array}{c}\text { KDB } \\
\text { / BC }\end{array}$ & $\begin{array}{c}\text { House } \\
\text { Plan }\end{array}$ & $\begin{array}{c}\text { Home } \\
\text { Function }\end{array}$ & Façade & Material \\
\hline The Comfort of Excess and Adding Space & A & SA & A & SA & SA \\
\hline Security (Secure as Physically and Psychic, Outside and Inside Threats) & SA & SA & A & A & SA \\
\hline Recognition (as Symbol / Identity from Façade Development, Great and Valueable) & SA & SA & SA & SA & SA \\
\hline
\end{tabular}

$\mathrm{SA}=$ Strongly Affects, $\mathrm{A}=$ Affects

Source: Personal Analysis, 2018 


\section{Conclusions}

There was a change with a varying percentage of occupancy change rates, namely changes in the basic coefficient of buildings, changes in residential plans, changes in occupancy functions, changes in spatial layout in dwellings, changes in residential facades and changes in residential materials. The rate of change is influenced by socio-demographic aspects, namely the stages of development in family life, income, education, work and socio-economic status.

On the other hand, the level of change according to the occupants is strongly influenced by the aspect of the need for comfort, in this case, change adds to the area of space and new types of space that are adequate as needed. The development of occupant activities, the security aspect of a dwelling must be able to fulfil the sense of physical and physical security of the occupants against threats coming from outside or from within, and the desired aspect of house recognition can become a symbol or identity of the occupants, in this case by changing the appearance of the building into a "great" and "valuable" house. The concept of a healthy home is a home design that can be tailored to the needs and desires of its occupants.

\section{REFERENCES}

[1] Gonzalez-Caceres A, Bobadilla A, Karlshøj J. Implementing post-occupancy evaluation in social housing complemented with BIM: A case study in Chile. Building and Environment, vol. 158, pp. 260-80, 2019.

[2] Dikmen N, Elias-Ozkan ST. Housing after disaster: A post occupancy evaluation of a reconstruction project. International Journal of Disaster Risk Reduction, vol. 19, pp. 167-78, 2016.

[3] Brioso X, Humero A, Murguia D, Corrales J, Aranda J. Using post-occupancy evaluation of housing projects to generate value for municipal governments. Alexandria Engineering Journal, vol. 57, no. 2, pp.885-896, 2018.

[4] Husin HN, Nawawi AH, Ismail F, Khalil N. Preliminary survey of integrated safety elements into post occupancy evaluation for malaysia's low cost housing. Procedia-Social and Behavioral Sciences, 36, pp. 583-590, 2012.

[5] Pretlove S, Kade S. Post occupancy evaluation of social housing designed and built to Code for Sustainable Homes levels 3, 4 and 5. Energy and Buildings, vo. 110, pp. 120-34, 2016.

[6] Kaitilla S. Post-occupancy evaluation in self-help housing schemes: Tensiti Settlement, Lae, PNG. Cities, vol. 11, no. 5, pp. 312-24, 1994.

[7] Dabaieh M, Maguid D, El Mahdy D, Wanas O. An urban living lab monitoring and post occupancy evaluation for a Trombe wall proof of concept. Solar Energy, vol. 193, pp. 556-67, 2019.
[8] Woo J. A post-occupancy evaluation of a modular multi-residential development in Melbourne, Australia. Procedia Engineering, vol. 180, no. 365-72, 2017.

[9] Wijegunarathna EE, Wedawatta G, Prasanna LJ, Ingirige B. Long-term satisfaction of resettled communities: An assessment of physical performance of post-disaster housing. Procedia Engineering, 212, pp. 1147-1154, 2018.

[10] Strelets K, Perlova E, Platonova M, Pankova A, Romero M, Al-Shabab MS. Post occupancy evaluation (POE) and energy conservation opportunities (ECOs) study for three facilities in SPbPU in Saint Petersburg. Procedia engineering, 165, pp. 1568-1578, 2016.

[11] Budiarso T, Tinjauan Optimalisasi Biaya Dan Waktu Menggunakan Metode Least Cost Scheduling (Studi Kasus: Proyek Fly Over Arif Rahman Hakim, Depok), Undergraduate thesis, Universitas Indonesia, 2007.

[12] Preiser WF, White E, Rabinowitz H, Post-Occupancy Evaluation (Routledge Revivals). New York: Routledge, 2015 .

[13] Office of Public Works (DPU). Pedoman Teknis Rumah dan Bangunan Gedung Tahan Gempa. Jakarta: The Ministry of Public Works and Housing, 2006.

[14] Bell PA, Baron RA. Aggression and Heat: The Mediating Role of Negative Affect 1. Journal of Applied Social Psychology, vol. 6, no. 1, pp. 18-30, 1976

[15] Morris, EW., \& Winter, M. Housing, family, and society. New York: Wiley, 1978

[16] Morris PE, Cook N. When do first letter mnemonics aid recall?. British Journal of Educational Psychology. 1978 Feb; 48(1):22-8.

[17] Nutt JG, Woodward WR, Hammerstad JP, Carter JH, Anderson JL, The "on-off" phenomenon in Parkinson's disease: relation to levodopa absorption and transport. New England Journal of Medicine, vol. 310, no. 8, pp. 483-488, 1984

[18] Anderson R, Carter I, Human behavior in the social environment: A social systems approach $\left(3^{\text {rd }}\right.$ ed.). New York: Aldine, 1984.

[19] Habraken NJ. The structure of the ordinary: form and control in the built environment. Cambridge, MA MIT press; 2000 .

[20] Budihardjo E, Sejumlah Masalah Permukiman Kota. Bandung: PT. Alumni, 1998.

[21] Yuliastuti N, Widiastomo Y. Towards Better Social Housing Policy Based on Residents' Satisfaction: A Case Study at Sendangmulyo, Semarang, Indonesia. Journal of Sustainable Development, vol. 8, no. 2, pp. 149-160, 2015.

[22] Banerjee T, Southworth M (eds.), City Sense and City Design: Writings and Projects of Kevin Lynch, Cambridge, MA, The MIT Press, 1990.

[23] Kartikawati, N., Setyowati, E., Indrosaptono, D. The empirical analysis model on identifying sick building syndrome in hot humid tropical buildings. Civil Engineering and Architecture, vol. 9, no. 1, pp. 52-73, 2021. DOI: 10.13189/cea.2021.090105. 